\title{
Formalin-Fixed Paraffin-Embedded T-Cell (CD3) Slide
}

National Cancer Institute

\section{Source}

National Cancer Institute. Formalin-Fixed Paraffin-Embedded T-Cell (CD3) Slide. NCI

Thesaurus. Code C125611.

A biospecimen consisting of formalin-fixed, paraffin embedded CD3-positive B-cells

affixed to a slide for light microscopy. 